\title{
前立腺肥大症と膀胱䏦瘍の合併について
}

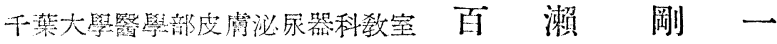 \\ (主任：竹內敎授) 小 林 健正
}

\section{ON THE CASES OF PROSTATIC HYPERTROPHY CONCURRENT WITH VESICAL TUMOR}

\author{
Goichi Momose and Kensei Kobayashi \\ Dept. of Dermatourology, School of Medicine, Chiba University
}

(Director: Prof. Dr. K. Takennuchi)

The report on 3 cases of prostatic hypertrophy concurrent with vesical tumor (papilloma, 2 cases: papillar carcinoma, 1 case), together with authors' views on this subject, is hereby submitted.

\section{〔I 緒 言}

前立腺肥大症已膀胱腫湟己は共に泌尿器科領域では頻

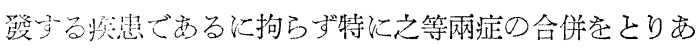
げ諭じをすつ㳊ないが, 最近 5 力年に我敉室で剔除術を 施行した前立腺肥大症 120 例中 3 例即与 $2.5 \%$ 亿膀胱

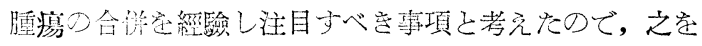
報告し併世て些亦の考按学加え諸兄の批判定仰ぎたいと 思引.

\section{[II]症例}

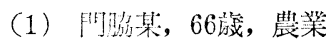

初晾：罗想29年5月25日

家族藲，既往歴：特記する事はない。

現病歷：詔和 28 年春頃より寒冷時に頻尿及び夜間多尿 定來し，29年 4 月初旬より尿が溷濁し，時に血尿定伴 い, 莗延性排永乞なり尿線も細くなつた。

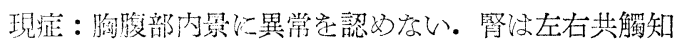

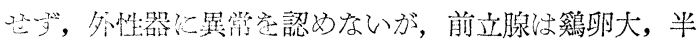

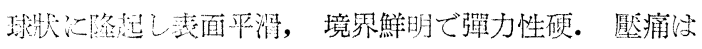
坎、表在淋巴腺の腫脹も認めない。血區 110〜75m

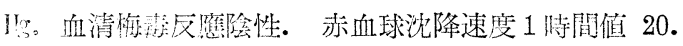

未稍血液像, 肝機能及び血清晶質量に異常なく, 總筒機 说も正学である。

膀胱鏡所見; 膀胱壁疗炎症所見安示し, 頂部上り後壁 に心けて著明尔肉柱形成老認め, 頂部より稍々後壁飞偏

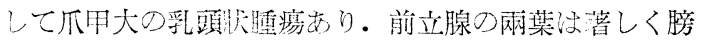

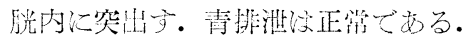

レ線所見; 第 1 圖に示主如く前立腺肥大像安签与る他 腫激像及び膀胱壁戀形は證しない。

よつて前立腺肥大症兼膀胱乳頭腫乙䛦斷し耽骨上前立

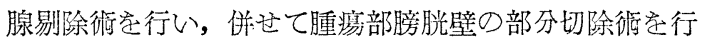
つた。術後顺調に經過し退院した。

剔出標本忟第 2 圆に示す如くであり, 又乞の組織學的 所見は, 前立腺は腺增殖及び賈腫様掏張があり, 一部に ほ結合織の增殖を證し炎症性圓形細胞の浸潤も見られる が惡性像注さない(第 3 圖). 膀胱腫序部々重層移行 上皮から成る乳頭腫であり一部に焱症性浸潤定伴了壊死 或柱小膿㿇の形成があるが惡性變化はない(第 4 圖). 之に接する膀脱上.皮潧殖するが其他特別な所見はな い. 即与組織的にも前立腺肥大症及び膀胱乳頭腫己確認 された.

（2）村井某, 77藏, 漁栄

初誩：昭和 29 年 11 月 18 日

家族歴，既往歴：特記することはない。

現病歴: 昭和 29 年 10 月下旬ょり頻尿及び莗延性排尿己 なり，11月8日より血尿となり残尿感が俄か儿現れた。

現症 : 胸腹部臟器に異常なく, 骨沙兩側共觸れない。 前立腺况境界明劃, 篤卵大に肥大し表面平滑で彈力性硬

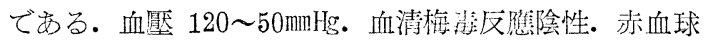
沈降速度 1 時閒值 64 . 血液像では轿度の資血及び白血 球增多症安認める. 黄担指数 12 , 血液尿素 $\mathrm{N} 18 \mathrm{mg} \%$ で あるが，其他の肝機能檢查及び血清晶質量注正常・水稀

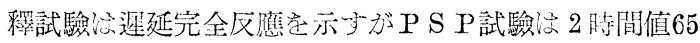


\%であった。

膀胱鏡所見; 前立腺兩葉流膀胱内に著しく突出し, 膀 腅三角部底縁より側壁の大部を占める乳頭状出血性の腫 瘳があるが前立腺との關連性经認められない。兩側尿管 口统腫瘍に陰蔽され詳細不明であり, 青は兩側共10分で 排泄を見ない。

尿道, 膀胱レ線像では前立腺の肥大定證するつ久であ つたが, 膀胱レ線像で认第 5 圖に示与如く前立腺肥大像 己重複して薄い腫瘍像を登明した。

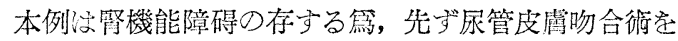
施行し, 二次的に膀胱及び前立腺の全剔除石空行つた。 術後經過证順調で退院した。

别出標本㳊第 6 圖に示与如く兩側尿管口後方より側壁 飞發生した多くは有悭性であるが一部廣基性の乳頭狀腫 㾤で, その組織學的所見は, 前立腺心腺組織の異型增殖 があるが細胞には特異な所見はない，即ち前立腺肥大症 つ組織像である(第 7 圖)。膀胼で注腫劰の部位によつて 異るが異型上皮細胞の浸润性設育が認められ䄉毛癌の初

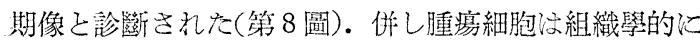
末だ淋巴䐑に入るには至っていない，腫演近接部膀胱壁 淡炎症性浸潤导伴了萄腫狀增殖, 即与 Cystitis cystica つ像が見られる。

(3) 風户某, 74歳, 農業

初彰 : 炤和 30 年 11 月 2 日

家族歴，既往歴：特記すべきことはない。

現病歴: 昭和 30 年 5 月 25 日小り運動後に血尿学來与よ ろになり，秋になって頻尿及で終末排躴痛が現れた。

現症 : 胸腹部に異常なく, 焣は兩側共臍高飞觸知す る. 前立腺沙鳩卵大, 表面平滑, 境界明膫にして稍々硬 い. 血孯 142～74mmHg. 梅赫血清反㮣陰性. 赤血球沈降 速度 1 㭙間值 23. 未梢血液像, 肝機能, 血清晶質星共 飞正常. 總腎機能略々正常.

膀胱鏡所見; 膀胱粘膜全體に充血があり，三角部は浮 腫狀である. 頂部より後壁にかけて肉柱形成渚明. 右尿 管口後側方に鳩卵大の椅圆形の結石を 1 ケ認め, 之に接 して小指頭大乳頭狀腫晹を認めた。 前立腺心膀胱晖内に 凸隆し殊に右葉が著明であつた，尿管口は正常で青排泄 む良好である. 即ち膀胱鏡的に络前立腺肥大症兼膀胱結 石々診斷し，腫瘍证炎症性浮腫と見做した。

乙線所見; 第 9 圖の如く前立腺の肥大像と結石像学證 する他特異な所見山ない。

よつて結石剔出学兼社耽骨上前立腺剔除石を行つた。

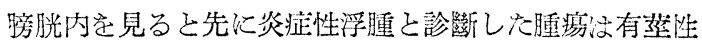

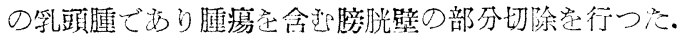
剔出標本以第10圖儿示方如く, 組織學的に综, 前立腺

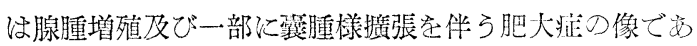

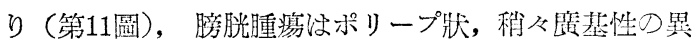
型基底細胞增殖の乳頭腫であつた (第12圖).

\section{〔III 考 按}

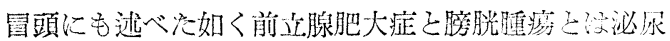
器科領域でありふれた疾患であり，之等兩症が好發年愉

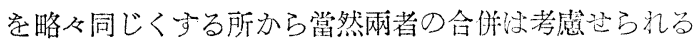
可きものであるに拘らず，特に此の問題堂採り亦代論じ たものはない。よつて我々は自己經驗例学も比本 問題に關卞る $2 ， 3$ の事項老論じたいと思う。

(1) 兩症の合併率

我々の最近 5 年間に於付る前立腺肥大症别唋術（恥骨 上式，耽骨後式，會陰式）を行つたもの结 120 例であ り，之に膀胱腫榢の合併学見て外科的處置在施したもの は上記の 3 例 $(2.5 \%)$ である。它諸家の統湖に垷? れた所と比较方ると，高橋・中川肥大症 299 例中膀脱

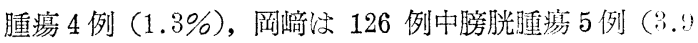
$\%)$, Higgins 2395 例中膀胱乳頭腫 3 例, 膀胱㺃 4 例 (1.7\%), Whitfield は黑人例で 112例中膀胱腫㟯 2 例 (1.7\%), Bulkley \& Kearns泣 774例（但乙前立腺籍 910.8\%含含)中膀胱灙23例( $2.9 \%$ ), Taylor, Kay-

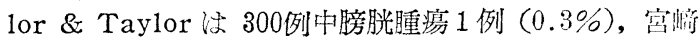

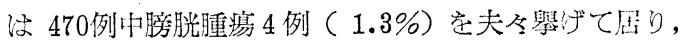
我々の數值は Bulkley \& Kearns に類似尘当. 他/j Waller \& Hamer は 373例（但し男子 260例）の膀脱 癌を分析して前立腺肥大症の合併学 124例即占症例の約 半數澢る高率に見出して居る.

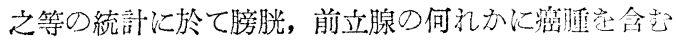

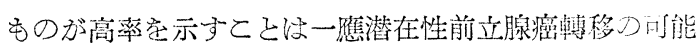
性をも考虑に入れ, 症例中に膀胱, 前立腺相互》癌侵裴 例を含导事を示唆するものではなからうか。我火の州例

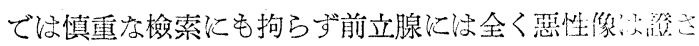

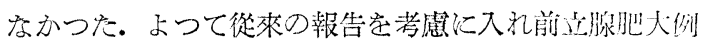

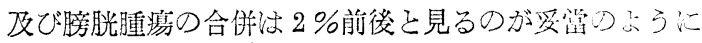
思われる。

(2) 年 跉

我くの 3 例は夫々 66 歳, 74歳, 77嵅であるが, 諸家の 前立腺肥大症及び膀胱腫瘍の統計（第 1 表及び第 2 表） に基く年路別頻度を見ると，肥大症で岕60嘁台，70歳

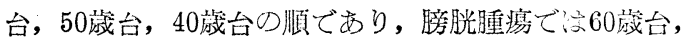
50歳台, 40歲台, 70藏台となり, 從つて合併の頻度心當 
第 1 表 前立腺肥大症の年蒢別頻度

\begin{tabular}{|c|c|c|c|c|c|}
\hline 著 & 例嚾 & 40 歲占 & 50 歲台 & 60 歲台 & 70 歲台 \\
\hline 天 & 67 & 0 & 8 & 32 & 24 \\
\hline Byrne & 347 & 4 & 46 & 137 & 126 \\
\hline Labess & 98 & 2 & 18 & 50 & 18 \\
\hline 崎 & 470 & 25 & 107 & 221 & 109 \\
\hline 崎 & 126 & 7 & 32 & 57 & 26 \\
\hline 大 & 239 & 17 & 53 & 114 & 43 \\
\hline $\begin{array}{r}\text { Swann \& } \\
\text { Mintz }\end{array}$ & 170 & 3 & 35 & 96 & 35 \\
\hline 高橋 -中川 & 299 & 9 & 59 & 146 & 60 \\
\hline 时村・金子 & 77 & 5 & 7 & 36 & 25 \\
\hline
\end{tabular}

第 2 表 男子膀胱腆瘍の年路令别頻度

\begin{tabular}{|l|r|r|r|r|r|}
\hline \multicolumn{1}{|c|}{ 著 } & 例數 & 40 歲台 & 50 歲台 & 60 歲台 & 70 歲台 \\
\hline Ash & 2104 & 308 & 626 & $\begin{array}{r}1044 \\
(60 \text { 歲以上) }\end{array}$ \\
\hline 原口・友目 & 139 & 14 & 28 & 49 & 9 \\
\hline 高 橋 等 & 172 & 27 & 51 & 61 & 19 \\
\hline $\begin{array}{c}\text { Kretschmer } \\
\text { 等 }\end{array}$ & 684 & 106 & 213 & 209 & 88 \\
\hline $\begin{array}{c}\text { Waller \& } \\
\text { Hamer }\end{array}$ & 260 & 28 & 64 & 92 & 49 \\
\hline \begin{tabular}{c} 
Hamer \\
\hline
\end{tabular}
\end{tabular}

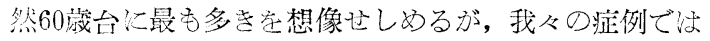
此の年畧域に於けるものは 1 例定數えるのでみで他の 2

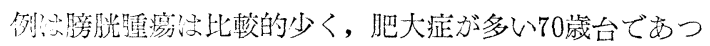
※，之を要するに我くの3 例の經驗ではあるが, 兩者合

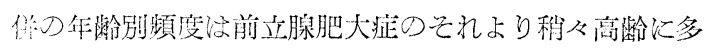
いと考兊たい。

（3）血尿

我々の症例の症狀就て詳細な分析学行つたが, 初發

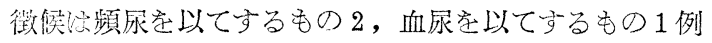
であり, 徵候自覺小り初診までの期間梳 1 月より 1 年に 達しているが, その主訴がいずれも血尿であつたととは

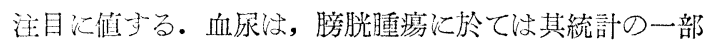
保れてみても Kretschmer 等 $91.5 \%$, Ash $75 \%$, Johnson $94 \%$, Waller \& Hamer $83 \%$, 高橋等 76.4 $\%$, 原口・友田 $92.9 \%$ 亡なつて居り, 他の膀胱症狀に预 先し殆己゙必發の症狀であるが, 前立腺肥大症汇和ける血 尿况滈橋・ 中川 $1.3 \%$, 阿久津 $5 \%$, 田村 - 金子 $9.0 \%$, 门川・荒尾 9.5\%，大藤 $11.7 \%$ ，岡㠃 $15.0 \%$, Byrne $16.1 \%$, Whitfield 19\%（但し後 2 者怡前立腺癌学含

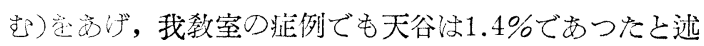
べて居り, 本邦統計の多くは10\%を出ない. 從つて血尿
以前立腺肥大症で洨頻登する症候で饮ない。よつて前古 腺肥大症と誩斷された症例でも就中60歳以上の血尿を主

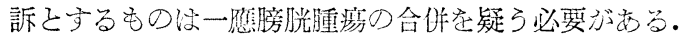

（4）診斷化當つての注意

前立腺肥大症診斷々一部の學者㴔性尿閉，尿路感染 の急性增惡学惧れて下降性腎孟撮影術安以てその第一手 段乞するが，我々沙前立腺肥大症に對しても膀胱腫瘁に 對与るFenwickの“Always cystoscope, never sound for symptomless hematuria” 從方可きものと考元 る. 我从の第 1 , 第 3 例怾膀胱レ線像に於ては前立腺肥 大像安登与゙るのみであつたが，膀胱鏡检查で膀胱内腫湯 の合作を確珰したものである. 又前立腺肥大症は大部分 の症例江膀胱炎を合併吉る故, 之纪基く泡状炎症性浮腫

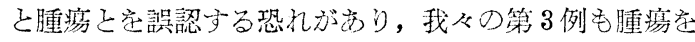
炎症性浮腫と誤つたものである，從つて血尿を見る前立 腺肥大症に行引膀胱鏡检查珱常に膀胱腫瘍の合併念頭 に㧍き慎重な注意を以て行う必要がある。

（5）前立腺肥大症及び膀胱腫㾓の關連性

我从の 3 例に扢ける合併膀胱腫疼は夫火頂部, 三㑲部 底縁，側壁或は尿管口後方に發生したもので，2 例烛乳 頭睡，1例は癌腫であつたが，何礼も肉眼的及で組織學 的に前立腺已の直接の關係㳊認め得劣示つた。

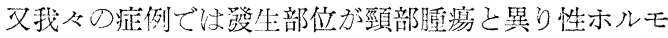

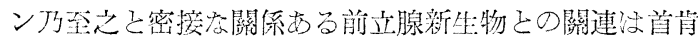

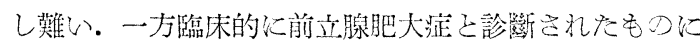
潜在性前立腺澏が $4.7 \%$ 29.4\%の頻度にあるといい，

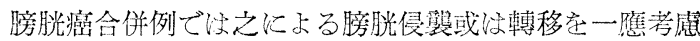
主る必要があるが，我ふの第 2 例恣，肥大前立腺淰肉眼

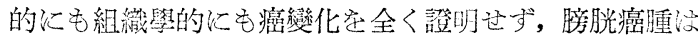
組織學的飞乳頭腫の惡性變化を來したものと思われた。 よつて膀胱乳頭腫を合併した他の 2 例と共に网者流各々

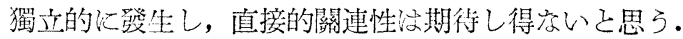

（6）肥大症以膀胱融癔の合併守る因子

之等兩疾患の病因論の確立せざる今日に於ては全く不 明であり, 肥大症なる尿路閉塞が尿中の化學的腫瘍源物 質の膀脱内停滞艺招くふ，續發結石の刺戟飞基く心， Kirwin の云う Virus の膀脱内增殖の促進学來与の か, 又 Dukes の大腸菌感染江對与る防禦的反憵を高为 るのか詳ではない。

併し我从の症例では，病狀自覺より來院までの日数は 夫从 1 月，5月であるが，剔出前立腺重量は $33 \mathrm{~g} ， 35$ $\mathrm{g}, 30 \mathrm{~g}$ であり本症の存在即与排尿障碍㹥既飞長期江す， たり存在した事が推测され，他方膀胱内腫懪出，筈 1 
第 1 圖 門脇尿道・膀胱レ線像

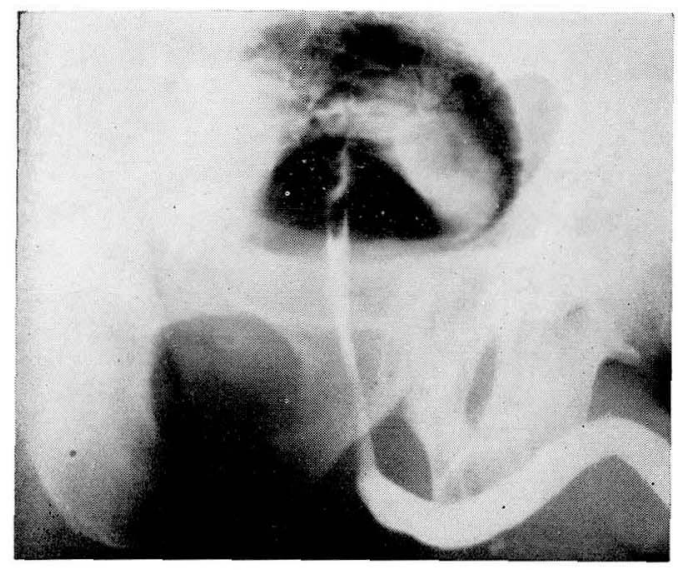

第 2 圖 門脇剔出標本

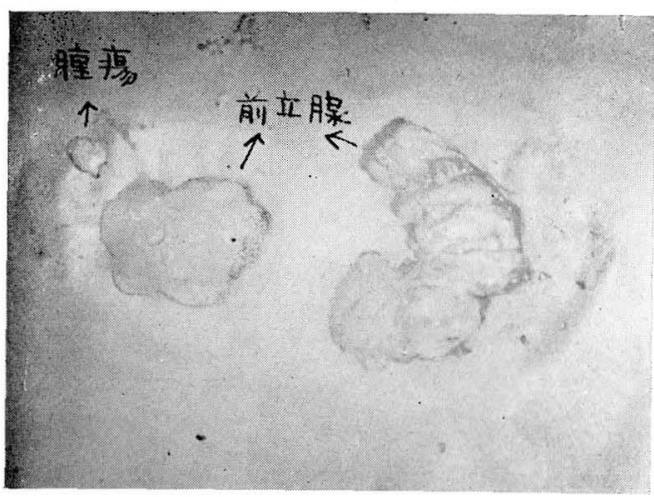

第 3 圖 門脇前立腺組織像

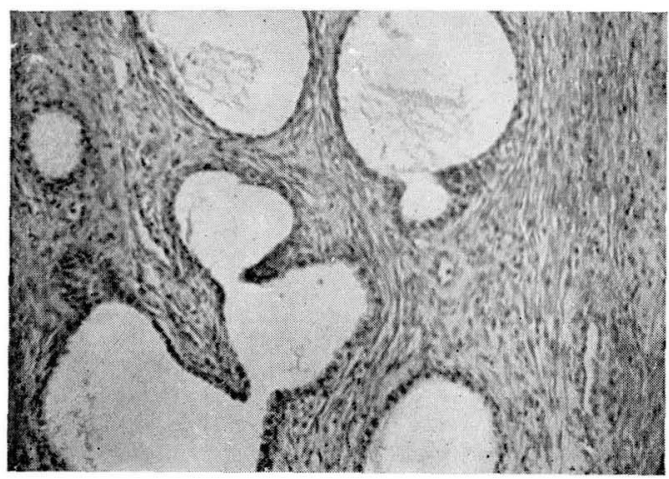

第4 圖阿脇膀胱組織像

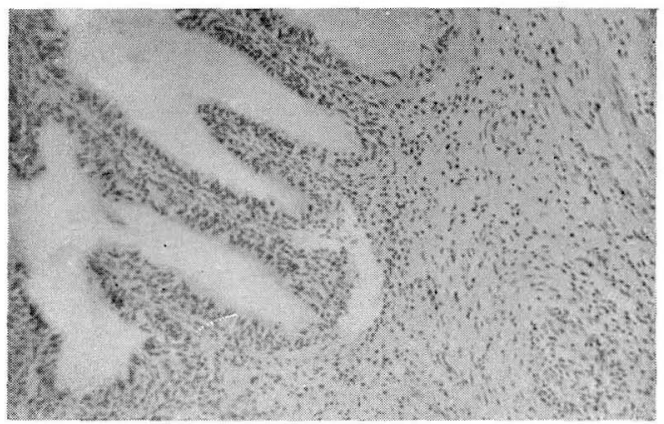

第 5 圖 村井膀胱レ線像

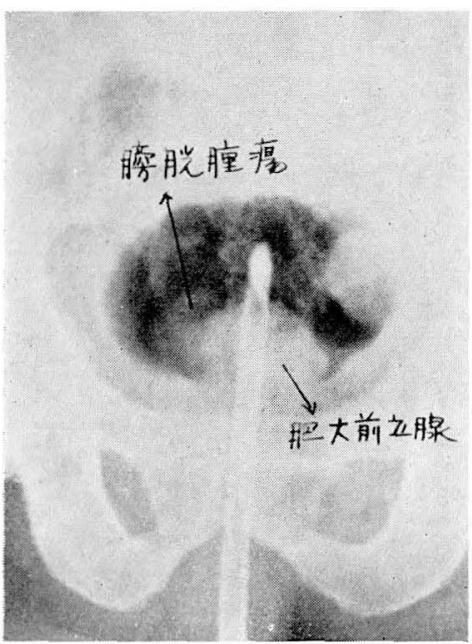

第 6 圖 村井剔出標本

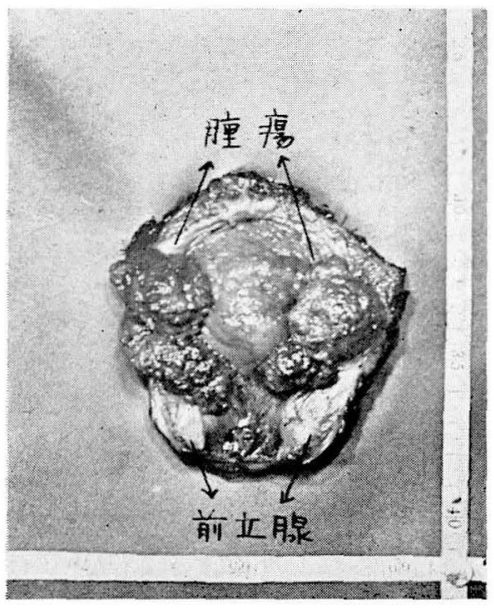


第 7 圖 村井前立腺組織像

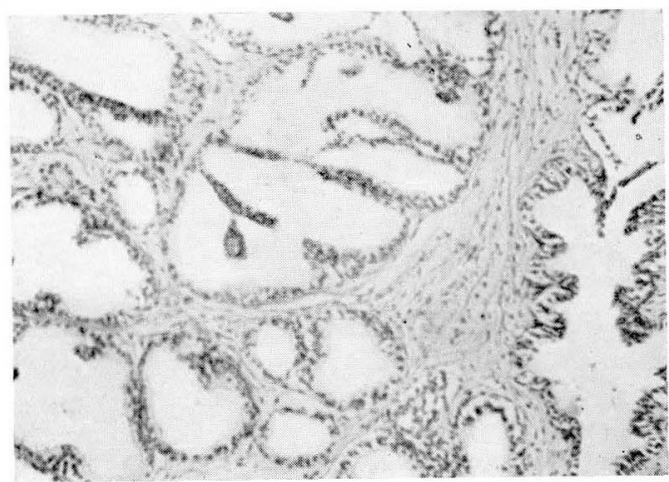

第 8 圖 村井膀胱組織像

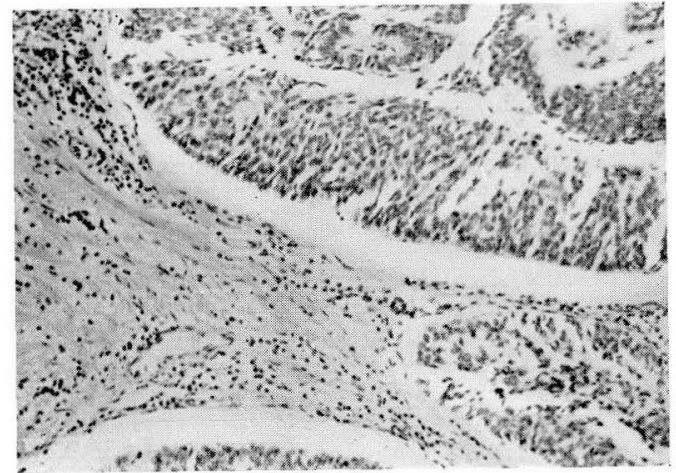

第 9 圖 風戸尿道膀腃

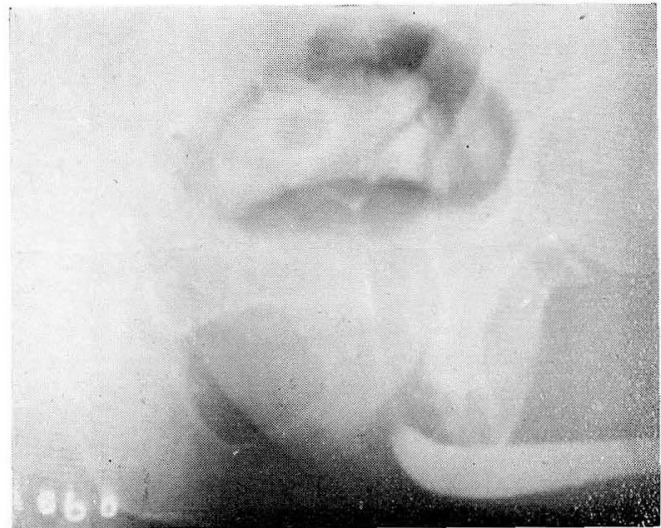

第10圖 風戶剔出標本

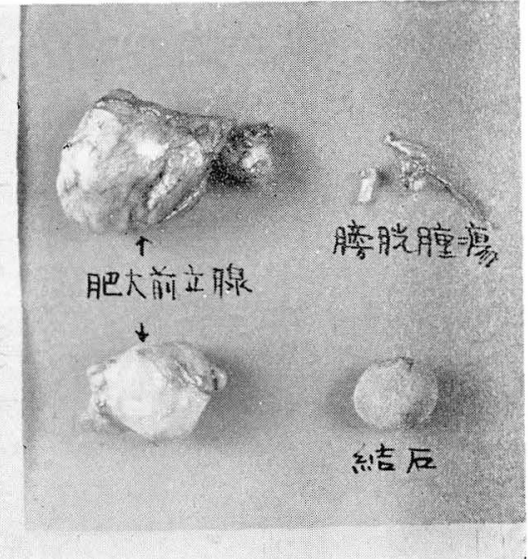

\section{第11圖 風戶前立腺組織像}

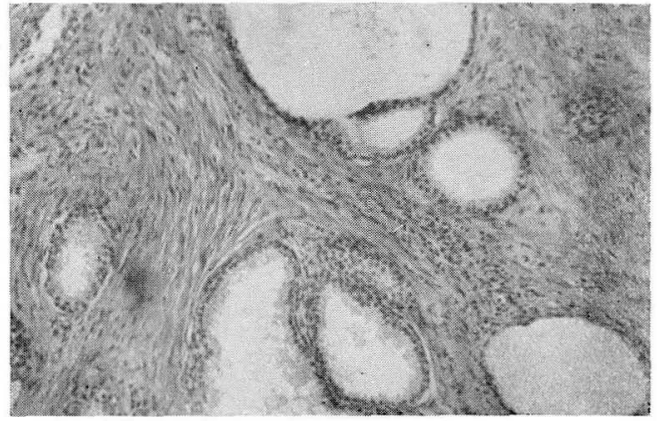

第12圖 風戶膀脂組織像

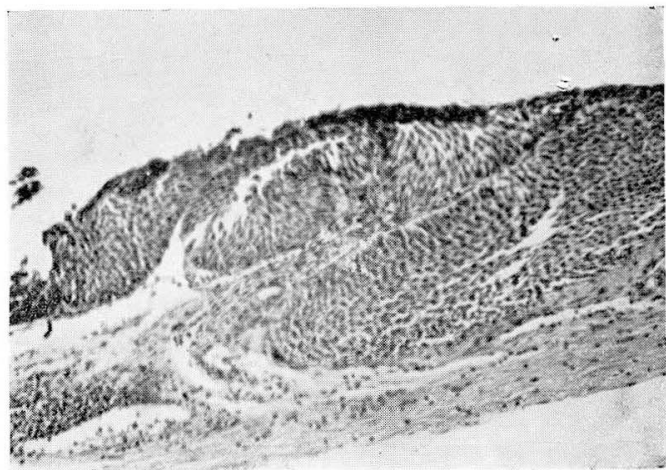


例, 第 3 例証何れも初期乳頭腫であり, 第 2 例怯初期乳

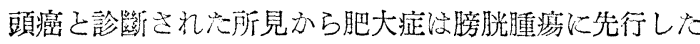
事は明白であり，象に角前立腺肥大症が間接的に膀胱腄 序形成に好條件を提供したものと考える.

以上小數例ではあるが我くの經験した 3 例を基として 膀胱腫痛学合併した前立腺肥大症の 2,3 の事項に就て 論じたが，前立腺肥大症㟍良性であり根治手石により全

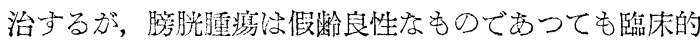
には惡性經過定己る事が多いので，之を見落す事㥙患者 の豫後に重大な影響是與えるものである，幸い兩者の合 併頻度埌低率ではあるが，前立腺肥大症特に血尿定伴う 症例统膀胱鏡检查を主とする慎重詳細な检索により膀胱

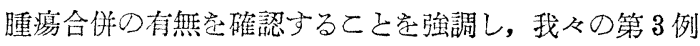
の如く琎前の診断不確實な症例々は恥骨上前立腺剔除術 を行い, 其際膀胱壁の精査を行いたい.

\section{[IV]結 語}

（1） 3 例の膀胱腫癔它合併した前立腺肥大症例を報 告した。

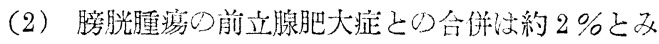
たい.

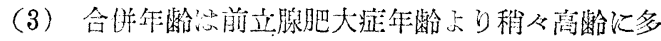
いと考えた。

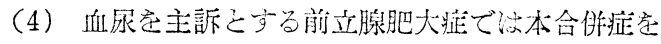

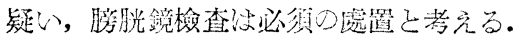

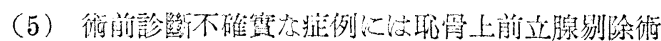

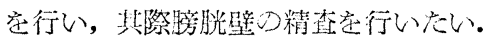

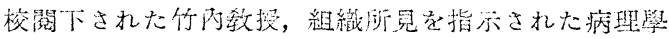

湤澤敎授に澎す。

佮本論交の要旨は第209问日本泌尿器科學會束京地方 會で發表した。

\section{主參考文獻}

1）阿久津：日泌尿會誌, 24, 901, 昭 10 .

2) 元谷：千菜醫會誌， $\mathbf{3 1}, 644$, 昭 31 .

3) Ash: J. Urol., 44, 135, 1940.

4) Bulkley \& Kearns: J. Urol., 68, 724, 1952.

5) Byrne: J. Urol., 67, 121, 1952.

6) 原口・友明：皮紀要，46, 204, 昭 25 .

7) Higgins: Cleveland Clinical Quarterly, 14, $181,1947$.

8）市川・荒尾：皮梷と泌尿， 15，133，昭 28.

9）伊藤：日泌冢會誌， 45, 467, 昭 29.

10) Johnson: J.A.M.A., 135, 1146, 1947.

11) Kretschmer, Barringer, Braasch, Dean, Ferguson, Keys \& Smith: J. Urol., 31, 423, 1934.

12) Labess: J. Urol., 68, 893, r952.

13）宮崎：泌尿紀要，1，22，昭 30 .

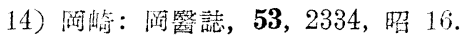

15) 大藤：阙醫誌， 63, 128, 昭 26.

16) Swann \& Mintz: J. Urol., 26, 67, 1931.

17）高橋・小松・甲田・㞋日：日泌死會訫，35, 129, 昭 18 .

18）高橋・中川：臨皮泌， 5, 763，昭 15.

19）四村 - 金于：日泌尿會誌， 19，17，昭 5.

20) Taylor, Kaylor \& Taylor: J. Urol., 74,129, 1955.

21) Waller\& Hamer: J. Urol., 64, 651, 1950.

22) Whitfield: J. Urol., 64, 106, $195 \mathrm{~s}$. 